\title{
The State of Climate Change Adaptation in Canada's Protected Areas Sector
}

\author{
Christopher f. Lemieux, Thomas f. Beechey, Daniel f. Scott, and \\ Paul A. Gray
}

Ed. note: Because of space limitations in this issue, a companion piece by the same set of authors, "A Model Process for Developing Adaptation Options for Natural Heritage Areas in an Era of Rapid Climate Change," will appear in the next edition of The George Wright Forum.

\section{Introduction}

Protected AREaS Were FirSt ESTABlished to preserve scenic wonders and tourist attractions. In recent years, the rationale has evolved to become a cornerstone of biodiversity conservation and ecological sustainability, as well as an important barometer of world ecosystem health and human condition (CBD 1992; Millennium Ecosystem Assessment 2005; Government of Canada 2009). As of 2010, Canada's terrestrial protected areas number more than 4,850 spanning 101.2 million ha and representing 9.92\% of Canada's total land base (Figure 1; CCEA 2010). In addition, approximately 45,280 sq km (0.12\%) of Canada's oceans are protected (CCEA 2010). Collectively, the establishment and management of protected areas are central to Canada's commitment to Article 8 on "In-situ Conservation" of the United Nations (UN) Convention on Biological Diversity (CBD 1992). Climate change has begun to impact critical, once relatively stable, climate regions and is now recognized to be one of the most serious threats to biodiversity and the conservation thereof (CCME 2003; Root et al. 2003; Thomas et al. 2004; IPCC 2007b; Lemmen et al. 2008; CBD 2009). Both the Intergovernmental Panel on Climate Change (IPCC) Fourth Assessment Report (AR4) and Canada's national synthesis on climate change, From Impacts to Adaptation: Canada in a Changing Climate 2007 (Lemmen et al. 2008), have clearly substantiated that climate change induced by human-generated greenhouse gas (GHG) emissions is now implicated in a myriad of coincident impacts: perturbations in regional temperature regimes and precipitation patterns, severe weather events, sea level rise, and changes in ecosystem composition, structure, and function (IPCC 2007a, 2007b; Lemmen et al. 2008).

Parks and other forms of protected areas in Canada have a wide range of management objectives, including the permanent protection of representative ecosystems, biodiversity,

The George Wright Forum, vol. 28, no. 2, pp. 216-236 (2011).

(C) 2011 The George Wright Society. All rights reserved.

(No copyright is claimed for previously published material reprinted herein.)

ISSN 0732-4715. Please direct all permission requests to info@georgewright.org. 


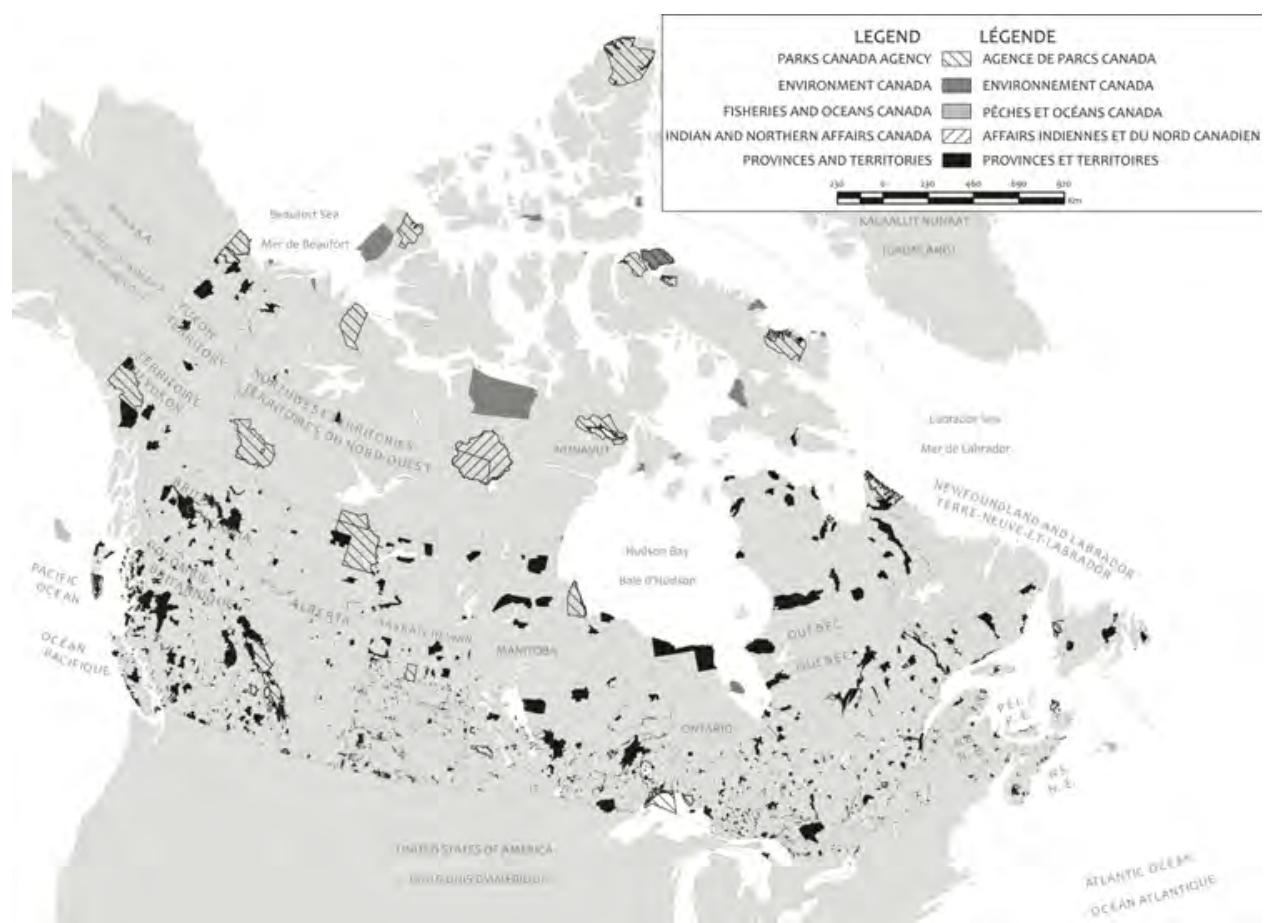

Figure 1. Canada's protected areas include a wide range of designations comprising $9.92 \%$ of the area of the country. Small sites are not conspicuous for southern Ontario and other southern settled regions due to limitations of scale. Source: CCEA 2010.

and other significant elements of natural and cultural heritage values, and the provision of opportunities for outdoor recreation, education, and appreciation of natural and cultural heritage, all of which will be affected by climate change. In ecological terms, the anticipated shifting of species distributions-consequences less commonly visible than impacts on human settlements and livelihoods-may well have the most devastating long-term impacts. Bioclimatic envelope projections of future flora and fauna distributions in Canada and elsewhere suggest that species hosted in parks and other forms of protected areas of the future will bear little resemblance to those of today (e.g., Henderson et al. 2002; Malcolm, Liu, et al. 2002; Malcolm, Markham, et al. 2002; Scott et al. 2002; Hamann and Wang 2005; Lemieux and Scott 2005; Malcolm et al. 2006; McKenney et al. 2007a, 2007b; Lawler et al. 2009). Furthermore, evidence from virtually all meta-analyses on species response to climate change overwhelmingly suggests that species will be impacted negatively, possibly resulting in levels of mass extinction (e.g., Thomas et al. 2004; Malcolm et al. 2006; IPCC 2007b). For example, the IPCC (2007b) has suggested that approximately 20-30\% of Earth's plant and animal species are likely to be at increased risk of extinction if increases in global average temperatures exceed $1.5-2.5^{\circ} \mathrm{C}$. Furthermore, according to Pounds and Puschendorf (2004) and others (e.g., Opdam and Wascher 2004), estimates of species extinction resulting from climate change may be optimistic when the synergistic effects of habitat fragmentation, habitat destruction, and climate change on the landscape are considered. 
Indeed, as fixed assets established to conserve samples of ecosystems and species, protected areas worldwide are vulnerable to the shifting ecological matrix induced by climate change. It is conceivable that the synergistic effects of climate change and other incompatible land-use practices could render many protected areas as "conservation deathbeds" if adequate adaptation measures are not put in place. As a result of these potential outcomes, climate change has been increasingly recognized as a key emerging issue for agencies and organizations responsible for the management of parks and other forms of protected areas (e.g., Hannah et al. 2002; Scott et al. 2002; Lemieux and Scott 2005; Welch 2005; Baron et al. 2009; Heller and Zavaleta 2009; West et al. 2009).

To that end, this article examines three aspects: (1) what climate change impacts are currently perceived by Canadian protected areas agencies and organizations to be affecting or anticipated to affect protected areas across Canada; (2) the perceived importance of climate change relative to other protected areas management issues in Canada; and (3) what policy, planning, and management responses (i.e., adaptations) have been developed or are being considered by protected areas agencies and organizations across Canada. Understanding how protected areas agencies and organizations view climate change (both independent of and with respect to adaptation and mitigation) is an important precursor to any attempt at developing an adaptation strategy. The results of the survey build on recent protected areas and climate change work conducted in Canada by both scientists (e.g., Scott and Suffling 2000; Scott et al. 2002; Lemieux and Scott 2005; Scott and Lemieux 2005; Lemieux et al. 2008; Lemieux et al. 2010; Lemieux et al., 2011; Lemieux and Scott, in press) and practitioners (e.g., Henderson et al. 2002; Welch 2005; Vandall et al. 2006) and provide an important overview of the state of climate change adaptation in Canada's protected areas sector. The survey also establishes an indication of the current capacity (as self-evaluated) of agencies to respond to the climate change issue.

\section{The state of climate change adaptation in Canada's protected areas sector: The Canadian protected areas and climate change survey}

Adaptation involves making adjustments in decisions, activities, and thinking because of observed or expected changes in climate, in order to moderate harm or take advantage of new opportunities (IPCC 2007b). Adaptation is a necessary complement to the reduction of GHG emissions in addressing climate change (IPCC 2007b). Climate change adaptation planning in the protected areas sector is important for a number of reasons: (1) climate change is already impacting protected areas' ecosystems and resources (e.g., the distribution, phenology, and composition of species; landscape physiography; and the provision of recreational opportunities); (2) despite efforts to reduce GHG emissions, some level of humaninduced change will be realized in the 21st century; (3) proactive adaptation will be more cost effective and efficient in reducing the potential for irreversible impacts, such as species extinctions, and in exploiting potential benefits than reactive responses (Smit et al. 1999; Burton et al. 2002; Root et al. 2003; Parmesan 2006; Stern 2006; Thomas et al. 2006; IPCC 2007a; Herrod and West 2008; Lemmen et al. 2008; Pearson and Burton 2009). Most importantly, protected areas agencies will need to be adaptive in order to deliver on their various protected areas- and biodiversity-related mandates, such as the perpetual protection of 
representative elements of natural heritage (e.g., Government of Canada 2000; Government of Ontario 2007). Pielke (1998) and Vedwan and Rhoades (2001) stress that the way in which decision-makers perceive climate change is a significant factor influencing the climate adaptations that are actually adopted. Moreover, there is an urgent need identified in the literature for ongoing, rigorous "accounting" of climate change adaptation (Thompson et al. 2006). While Scott and Lemieux (2005) and others (e.g., Welch 2005; Baron et al. 2009; Heller and Zavaleta 2009; West et al. 2009; Lemieux et al. 2011) have produced climate change adaptation portfolios for protected areas based on syntheses of the scientific literature, these are potential adaptations and do not reflect what adaptation is occurring or planned in practice.

In response to these identified research needs in the field of climate change adaptation generally, but particularly in the protected areas and biodiversity conservation sectors, and with the endorsement of the North American Chapter of the International Union for Conservation of Nature's World Commission on Protected Areas, the University of Waterloo, and the Canadian Council on Ecological Areas (CCEA) initiated a collaborative protected areas and climate change survey to assess the state of current efforts on climate change adaptation employed by Canadian protected areas agencies and organizations.

\section{Survey design, sampling method, and participants}

The authors designed the survey instrument in consultation with the CCEA. The CCEA, which has complete federal, provincial, and territorial protected areas agency representation, was incorporated in 1982 as a national, not-for-profit organization with a mission "to facilitate and assist Canadians with the establishment and management of a comprehensive network of protected areas representative of Canada's terrestrial and aquatic ecological natural diversity" (CCEA n.d.). A central function of the CCEA is to mobilize experts and practitioners to advance work on subject areas and issues that are critical for designing, planning, and managing protected natural areas. Climate change has been recognized as an issue of high priority in the CCEA's current Strategic Plan (CCEA 2009). Its importance has been further highlighted by all Canadian protected areas jurisdictions participating in a recent CCEA northern protected areas survey (Wiersma et al. 2006). The survey was reviewed by an advisory committee that included jurisdictional representatives of the CCEA and researchers from the University of Waterloo. A pre-test was administered to four CCEA jurisdictional representatives to assess the clarity of the survey design, its appropriateness to the audience, and whether it achieved the aims of the research. Primarily closed-ended questions were used and grouped into sections of related questions. Questions were grouped by themes to ensure the flow and sequence of the survey was appropriate to the respondents' understanding of the research purpose and to maintain their willingness to provide meaningful responses. In total, 23 questions were asked of respondents and, depending on their responses, up to nine follow-up questions could be asked.

Survey participants were selected from government agencies and environmental nongovernmental organizations (ENGOs) that plan, establish, or manage protected areas in Canada. The survey sample $(n=35)$ was selected to represent the full spectrum of agencies and organizations operating at varying geographical and jurisdictional scales across Canada (Table 


\section{Federal Government $(n=4)$}

- Environment Canada, Canadian Wildlife Service*

- Parks Canada Agency*

- Canadian Heritage Rivers (of Parks Canada Agency)*

- Department of Fisheries and Oceans, Marine Protected Areas*

\section{Provincial Government $(n=13)$}

- Government of Alberta, Alberta Community Development, Parks and Protected Areas*

- Government of British Columbia, British Columbia Ministry of Environment*

- Government of Manitoba, Manitoba Conservation*

- Government of New Brunswick, Department of Natural Resources*

- Government of Newfoundland and Labrador, Department of Environment and Conservation, Parks and Protected Areas Division*

- Government of Nova Scotia, Environment and Labour, Protected Areas Branch*

- Government of Nunavut, Department of Environment, Nunavut Parks and Special Places*

- Government of Ontario, Ontario Ministry of Natural Resources (MNR), Ontario Parks*

- Government of Prince Edward Island, Forests, Fish, and Wildlife Division, Department of Environment, Energy and Forestry*

- Gouvernement du Québec, Ministère du Développement durable de l'Environnement et des Parcs*

- Government of Saskatchewan, Saskatchewan Environment*

- Government of Yukon, Yukon Environment, Parks Branch*

- Government of Northwest Territories, Department of Industry, Tourism and Investment, Tourism and Parks Division*

\section{Environmental Non-governmental Organizations (ENGOs) $(n=13)$}

- Canadian Boreal Initiative (CBI)

- Canadian Biosphere Reserves Association (CBRA)

- Clayoquot Biosphere Trust

- Deh Cho Land Use Plan

- Long Point Biosphere Reserve

- Nature Canada

- The Nature Conservancy of Canada (NCC)

- Wildlife Habitat Canada (WHC)

- World Wildlife Fund (WWF) Canada

- Carolinian Canada Coalition (CCC)

- Ontario Nature

- Yellowstone to Yukon (Y2Y)

- Canadian Parks and Wilderness Society (CPAWS)

\section{Other $(n=5)$}

- Federation of Canadian Municipalities

- Conservation Ontario

- Toronto and Region Conservation Authority (TRCA)

- Credit Valley Conservation Authority (CVCA)

- Niagara Escarpment Commission (NEC)

*= CCEA affiliate agency

Table 1. Summary of respondents who participated in the Canadian protected areas and climate change survey. 
1). Collectively, agencies included in the survey are responsible for at least 4,850 protected areas or about $99 \%$ of Canada's entire protected areas network both in terms of total number of protected areas and total hectares protected.

The survey pool included CCEA jurisdictional representatives working in principal federal departments $(n=4)$ and provincial/territorial ministries/departments $(n=13)$. In addition, a sample of other agencies that operate at smaller jurisdictional scales, such as municipalities and conservation authorities, were included $(n=5)$. First Nations and ENGOs that plan and establish protected areas independently or provide important research, capacity-building, and/or outreach functions within the Canadian protected areas community were also surveyed $(n=13)$. The survey was completed over a six-month period; follow-up communications continued until $100 \%$ of the pre-identified (purposive) sample had submitted their surveys on behalf of their respective agencies. A discussion of select survey results is presented below. The complete survey may be obtained by contacting the lead author.

\section{Results and discussion}

Perceptions of climate risk and vulnerability. When asked when the issue of climate change will be relevant to protected areas planning and management in their agency, all agencies and organizations considered climate change to be an important management issue for protected areas "now" (91\%) or in the very near future (i.e., 2020s) (100\%). Furthermore, $71 \%$ of the agencies surveyed either "strongly agreed" or "somewhat agreed" with the statement that "climate change will substantially alter protected areas policy and planning over the next 10 years." When asked the same question, but in the context of the next 25 years, virtually all respondents (94\%) "strongly agreed" or "somewhat agreed" with the statement. Although climate change was identified as an issue affecting the management of protected areas now, respondents ranked a number of other management issues ahead of the impacts of climate change (Table 2). However, when asked the same question in the context of 25 years from now, $60 \%$ of the agencies ranked climate change as an issue of greater importance than currently perceived. Climate change ranked as the second most important management issue to protected areas agencies 25 years from now, ranking only behind external threats, and associated human land-use patterns.

With respect to the range of climate change impacts expected to occur within protected areas, respondents indicated that the most important impacts will be on watersheds (including wetlands, water quality, and quantity), wildlife, and vegetation, with $89 \%$ of the agencies identifying climate change impacts on these features as either "very important" or "important." Impacts of climate change on both policy and management for protected areas also ranked high, with $80 \%$ and $74 \%$ of respondents identifying impacts on these functions as either "very important" or "important," respectively. Conversely, respondents took the position that the least important climate change-related impacts on protected areas will be those associated with revenues (with over a quarter assessing this issue to be "unimportant" and $31 \%$ assessing it to be "slightly important"), operations and development (i.e., infrastructure), and interpretation programs (with $37 \%$ of agencies assessing these issues to be "unimportant" or "slightly important"). 


\begin{tabular}{|c|c|c|c|c|}
\hline \multicolumn{4}{|c|}{ Perceived Importance } & \multirow{3}{*}{ Management Issue } \\
\hline \multicolumn{2}{|c|}{ Now } & \multicolumn{2}{|c|}{ Future } & \\
\hline Rank & Median & Rank & Median & \\
\hline 1 & 3 & $\begin{array}{c}\mathrm{I} \\
(\mathrm{n} / \mathrm{c})\end{array}$ & 2 & $\begin{array}{l}\text { External Threats (e.g., surrounding land-use, } \\
\text { habitat fragmentation) }\end{array}$ \\
\hline 10 & 8 & $\begin{array}{l}T-2 \\
(+8)\end{array}$ & 4 & Climate Change \\
\hline 2 & 3.5 & T-2 & 4 & $\begin{array}{l}\text { Human Land-use Patterns (e.g, roads, } \\
\text { population density) }\end{array}$ \\
\hline $\mathrm{T}-4$ & 5 & $\begin{array}{l}\mathrm{T}-4 \\
(\mathrm{n} / \mathrm{c})\end{array}$ & 5 & $\begin{array}{l}\text { Wildlife Management (e.g., species richness, } \\
\text { population dynamics, trophic structure) }\end{array}$ \\
\hline 3 & 4.5 & $\begin{array}{l}\mathrm{T}-4 \\
(-1)\end{array}$ & 5 & Rare/Endangered Species Management \\
\hline $\mathrm{T}-4$ & 5 & $\begin{array}{l}\mathrm{T}-6 \\
(-2)\end{array}$ & 6 & Water Quality/Air Quality \\
\hline 7 & 6 & $\begin{array}{l}\mathrm{T}-6 \\
(+1)\end{array}$ & 6 & Exotic Species (e,g., animal and plant) \\
\hline T-8 & 7 & $(n / c)$ & 7 & $\begin{array}{l}\text { Disturbance Frequencies (e.g., fire, insects, } \\
\text { floods) }\end{array}$ \\
\hline $\mathrm{T}-4$ & 5 & $\begin{array}{l}T-9 \\
(-5)\end{array}$ & 8 & $\begin{array}{l}\text { Visitor Stresses (e.g., public facilities, } \\
\text { interpretation centres) }\end{array}$ \\
\hline T-s & 7 & $\begin{array}{l}\mathrm{T}-9 \\
(-1)\end{array}$ & 8 & Contamination/Pollution \\
\hline
\end{tabular}

$\mathrm{T}=$ tie in ranking; value in parentheses indicates increase/decline in ranking $\mathrm{n} / \mathrm{c}=$ no change in ranking

Table 2. Current and future perceived importance of climate change relative to other protected areas management issues by Canadian protected areas agencies (based on median of rankings, 1-10, by respondents).

Climate change impacts, adaptation, and information needs. A clear majority (73\%) of respondents indicated that protected areas within their agency's jurisdiction were currently affected by climate change-related impacts. For example, respondents for all provincial/territorial jurisdictions and all federal departments indicated that at least one climate change-related impact was occurring within their protected areas. The remaining respondents $(27 \%)$ indicated that they were "not sure" whether or not protected areas within their jurisdiction were experiencing climate change-related impacts.

Figure 2 illustrates the range of climate change-related impacts reported to be occurring within Canada's protected areas network. Species range shifts and changes in physiography (e.g., shoreline erosion and glacial retreat) were the most common climate change-related impacts reported within Canada's protected areas, with 75\% of respondents reporting such impacts. Changes in species composition (i.e., the character of the vegetation within a protected area) and changes in disturbance regimes (e.g., forest fire frequency and pest/disease outbreaks) were also reported to be occurring within protected areas by nearly half of the respondents (41\%). Examples of "other" reported climate change impacts included sea level rise within migratory bird sanctuaries (MBSs) and national wildlife areas (NWAs) managed 


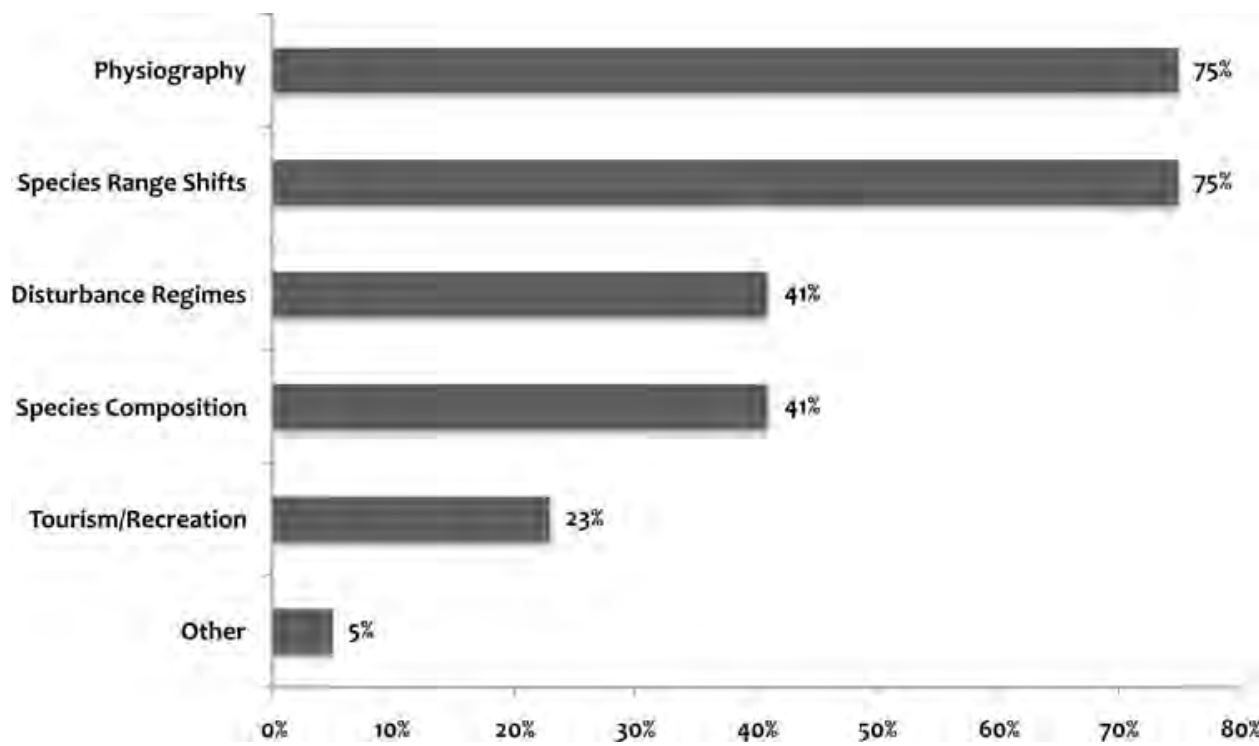

Figure 2. The range of climate change-related impacts reported to be occurring within Canada's protected areas network (percent of respondents reporting impact type and related impacts, e.g., on tourism/recreation).

by Environment Canada. Over the past century, sea level has risen approximately $32 \mathrm{~cm}$ in the Atlantic region (Parks 2006, 20), $4 \mathrm{~cm}$ in Vancouver, $8 \mathrm{~cm}$ in Victoria, and $12 \mathrm{~cm}$ in Prince Rupert, British Columbia (British Columbia Ministry of Water, Land and Air Protection 2002,30). (The increases in sea level noted here have been attributed to climate change. The differences in sea level rise between Pacific and Atlantic oceans are primarily due to eustatic change.)

Despite agency perceptions of the importance of climate change over the next 25 years, and a range of climate change impacts reportedly already occurring within Canadian protected areas, the majority of respondents $(83 \%)$ indicated that their agency had not completed a comprehensive assessment of the potential impacts and implications of climate change for their respective policy, planning, and management functions. This suggests that jurisdictional and agency-specific climate change impacts and implications for protected areas remain largely unknown in Canada. Ontario (Lemieux et al. 2007; Lemieux et al. 2008), Saskatchewan (Henderson et al. 2002; Vandall et al. 2006), and New Brunswick are the only provinces or territories known to have undertaken a climate change vulnerability assessment of protected areas and, with the exception of the World Wildlife Fund (WWF 2003), none of the other 12 ENGOs documented in the survey have completed such an assessment. Parks Canada Agency is the only federal department to have completed a climate change scoping report (Scott and Suffling 2000) and was one of the first internationally to do so.

No assessments have been completed for species-at-risk or for MBSs and NWAs, which include 144 sites protecting over 14 million ha, equating to nearly half of the total area protected by Parks Canada Agency (Environment Canada 2006). The lack of applied research on climate change and species at risk in Canada is of particular concern. Species currently 
classified as "at risk" may be among the most vulnerable to climate change and least capable of adapting naturally given their typically small populations, limited habitat, and exposure to external stressors. Clearly, there is a need for greater research and monitoring of climate change and consideration of the implications for species-at-risk management and policy. For example, Canada's Species at Risk Act (SARA) does not explicitly address the issue of climate change. Furthermore, limitations exist in SARA's time-sensitive definition of wildlife species eligible for protection in Canada (i.e., a species "native" to Canada or that has been present in Canada for at least 50 years) (Government of Canada 2003) and in the interpretation of SARA's mandates in the context of anthropogenically driven climate change. Despite these important implications, there has been inadequate attention, both in terms of monitoring and research, paid to climate change and species at risk within Environment Canada.

These findings reflect the limited scientific information available to protected areas agencies and the scarcity of resources that agencies have to devote to the climate change issue (see further discussion below). Generally speaking, agencies did not want more information on issues associated with atmospheric processes and climate modeling or on errors in and challenges with modeling the climate system (Table 3). Agencies expressed interest in information about the ecological consequences of climate change (all agencies and organizations noted that they would like more information on the issue) and the implications of climate

Table 3. Types of additional information Canadian protected natural areas agencies would like to have on various climate change-related issues (by percent of total number of responses).

\begin{tabular}{|c|c|c|c|}
\hline Research Theme & $\begin{array}{l}\text { Much More } \\
\text { Information }\end{array}$ & $\begin{array}{l}\text { Some More } \\
\text { Information }\end{array}$ & $\begin{array}{c}\text { No More } \\
\text { Information }\end{array}$ \\
\hline $\begin{array}{l}\text { Information on climate or } \\
\text { atmospheric processes }\end{array}$ & $12 \%$ & $59 \%$ & $29 \%$ \\
\hline $\begin{array}{l}\text { Errors and problems in } \\
\text { computer modeling of the } \\
\text { climate system }\end{array}$ & $6 \%$ & $50 \%$ & $44 \%$ \\
\hline $\begin{array}{l}\text { Detecting climate change } \\
\text { (e.g.. temperature trends) }\end{array}$ & $29 \%$ & $44 \%$ & $27 \%$ \\
\hline $\begin{array}{l}\text { Ecological consequences of } \\
\text { climate change }\end{array}$ & $79 \%$ & $21 \%$ & $0 \%$ \\
\hline $\begin{array}{l}\text { Impacts of climate change on } \\
\text { physiography }\end{array}$ & $41 \%$ & $50 \%$ & $9 \%$ \\
\hline $\begin{array}{l}\text { Impacts of climate change on } \\
\text { visitation (tourism and } \\
\text { recreation) }\end{array}$ & $35 \%$ & $41 \%$ & $24 \%$ \\
\hline $\begin{array}{l}\text { Implications of climate change } \\
\text { for planning, policy, and } \\
\text { management }\end{array}$ & $56 \%$ & $38 \%$ & $6 \%$ \\
\hline $\begin{array}{l}\text { Strategies for climate change } \\
\text { adaptation }\end{array}$ & $71 \%$ & $23 \%$ & $6 \%$ \\
\hline $\begin{array}{l}\text { Strategies for effective } \\
\text { communication of climate } \\
\text { change issues }\end{array}$ & $50 \%$ & $44 \%$ & $6 \%$ \\
\hline
\end{tabular}


Legislation, Policy and Planning

Selection, Evaluation and Design of Protected Areas

Management Direction (includingActive Management)

Operations and Development

Research, Monitoring and Reporting

Education, Interpretation and Outreach

Other

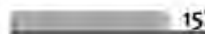

$15 \%$

$46 \%$

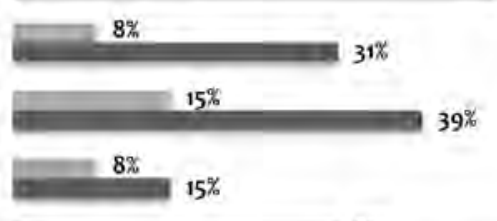

$31 \%$

$54 \%$

$46 \%$

$0 \%$

$8 \%$

$0 \% \quad 10 \% \quad 20 \% \quad 30 \% \quad 40 \% \quad 50 \% \quad 60 \%$

Figure 3. Climate change responses being undertaken or being considered by Canadian protected areas agencies (by major program area; percentages have been rounded).

change for policy, planning, and management strategies (with $94 \%$ of agencies noting that they would like more information on the issue). A large majority (94\%) of the respondents indicated that they wanted more information on strategies both for managerial responses (adaptation) to climate change impacts and strategies for effective communication of climate change issues. Although research interest in climate change communication and protected areas has increased in recent years (e.g., Schweizer et al. 2009), the research community has yet to evaluate how the revolution in climate information and information communication has enhanced visitor understanding of climate change impacts and how this information has translated into improved decision-making within agencies (Scott et al. 2011).

Of all respondents, only Parks Canada Agency, Ontario Parks, Government of Saskatchewan, Government of British Columbia, and WWF Canada acknowledged having a budget allocated specifically to respond to the challenges of climate change. Moreover, nearly half of the agencies surveyed (46\%) noted that they do not have an individual within their agency responsible for climate change-related issues (including legislation, policy, research, planning, management, and research and monitoring) and, for the agencies that do, climate change was perceived to be more of a future issue and not a current priority.

As Figure 3 illustrates, little action is currently being undertaken or considered by most protected areas agencies to deal with climate change-related issues. Moreover, despite the important role that protected areas could play in climate change detection, monitoring, and research, and in facilitating species adaptation, only half of the agencies reported that the magnitude and extent of climate change-related impacts in their protected areas are being investigated. While $97 \%$ of the agencies surveyed "strongly agreed" or "somewhat agreed" with the statement that "climate change detecting and monitoring should be a priority for protected areas agencies," less than a third (31\%) reported that they specifically monitor for climate change impacts. For example, Parks Canada Agency recently launched a monitoring program to measure, assess, and report on indicators of ecological integrity in national parks, including the effects of climate change. As a distributed monitoring network based in terres- 


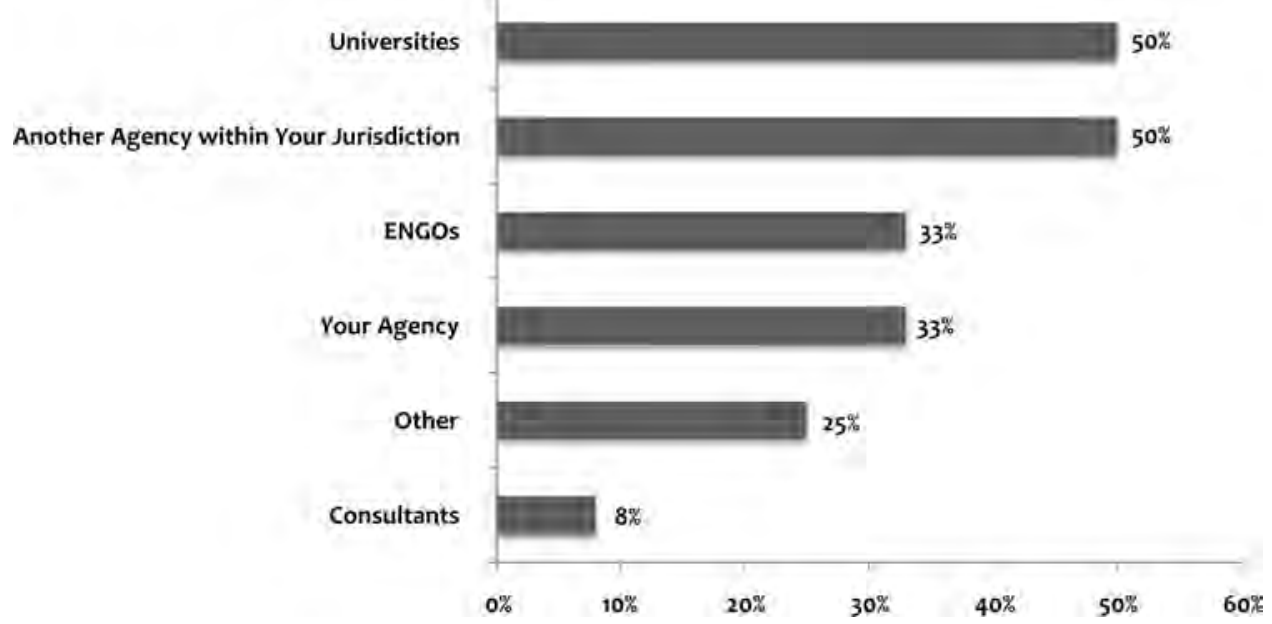

Figure 4. Climate change-related research being conducted in Canada's protected areas by "researcher type" (respondents could select more than one category; percentages have been rounded).

trial and marine protected areas, Parks Canada Agency's ecological monitoring program will form the basis for understanding impacts of climate change on the broader land and seascape, informing land-use planning, marine planning, environmental assessment, and other processes important for sustainable development (Keenleyside 2010).

Five agencies and organizations (14\%) have developed indicators for the long-term monitoring of climate change, although the extent of monitoring activities appears to be limited to solitary impacts, such as glacial retreat or single-species monitoring. Of the agencies involved in climate change research, much of the work has been conducted outside of their usual research and monitoring programs by various "researcher types" (Figure 4). Agencyuniversity partnerships in research appear to be particularly important in broadening scientific understanding of climate change and associated impacts in parks and other forms of protected areas in Canada.

Finally, despite the leading role that protected areas could play in educating the public about climate change, demonstrating its impacts and providing examples of adaptation, only six agencies (17\%) have incorporated climate change into public education, interpretation, and outreach programs. Importantly, however, a number of agencies, including Parks Canada Agency and Ontario Parks, have included climate change information on their websites and interactive posters aimed at youth, and some have begun incorporating climate change into park interpretation programs (see e.g., Parks Canada Agency 2010).

Adaptive capacity of Canada's protected areas sector. Despite the limited response to date on climate change, Canadian protected areas agencies expressed a strong desire to advance the climate change adaptation agenda. Over two-thirds of the agencies (69\%) "strongly disagreed" or "somewhat disagreed" with the statement that "there are too many uncertainties regarding climate change to develop adaptation strategies for protected areas" and nearly two-thirds indicated that formal climate change discussions have taken place within their agency. Most of these discussions have occurred through various awareness- and 
- "Priorities are not focused on climate change-lack of staff and financial resources for dealing with climate change are the main capacity issues."

- "Only one person is focusing on climate change issues and is self-appointed."

- "No staff, no financial resources, knowledgeable/scientifically trained staff to deal with the climate change issue."

- "We are under-sourced with no research/knowledge base and have difficulties meeting our current program needs."

- "We don't have confidence in science's ability in this instance to predict in a suitable time frame what issues will emerge; therefore, issues will likely have to be addressed as they emerge.... Climate change is inevitable but there is not much you can hang your hat on in terms of ecosystem and species responses."

- "More human and financial resources are needed to address arising issues and questions."

- "We haven't had the resources to even investigate what climate change could mean to our protected areas system but assume expansion is a way to mitigate, so that is where our focus is right now."

Table 4. Respondent feedback on capacity issues related to climate change and protected areas adaptation.

capacity-building initiatives, including workshops and other expert meetings. Nevertheless, protected areas agencies appear uncertain about how to proceed: $91 \%$ of the agencies conceded that they currently do not have the capacity necessary to respond effectively to climate change. Common reasons included lack of staff and financial resources and inadequate internal scientific capacity to deal with climate change (verbatim examples of the reasons cited in the survey are quoted in Table 4, maintaining respondent anonymity in accordance with University of Waterloo Office of Research Ethics guidelines). It comes as little surprise, therefore, that $83 \%$ of the agencies surveyed do not have a climate change policy or adaptation strategy specifically pertaining to protected areas or biodiversity conservation, or a climate change mitigation strategy (i.e., in-house plan to reduce GHG emissions). Moreover, of the 29 agencies currently without a climate change policy or adaptation strategy directly related to protected areas, only four (11\%) stated they were currently in the process of developing one.

\section{Moving forward on climate change adaptation in Canada's protected areas}

It has been estimated that species are currently in the "first order" of ecological response to modern climate change (i.e., adjusting phenotypes and geographic ranges; Barnosky et al. 2003). However, a growing number of researchers contend that the rapid loss of climate envelopes in which species and ecosystems have adapted over the past several interglacial periods would result in widespread turnover and extinctions (see Thomas et al. 2004; Malcolm et al. 2006; IPCC 2007a; Lawler et al. 2009, among others). The scientific literature on climate change adaptation overwhelmingly suggests that adapting now (i.e., mainstreaming climate change into policy, planning, and management program functions) will be more effective than adapting later; i.e., doing so will be more cost effective and efficient in reducing the potential for irreversible impacts, such as species extinction (e.g., Smit et al. 1999; 
Burton et al. 2002; Stern 2006; Pearson and Burton 2009). Overall, however, a significant gap remains between the perceived importance of climate change and the capacity (i.e., funding, staff expertise, etc.) of protected areas agencies and organizations to respond to the challenges of rapid climate change. Capacity constraints at the provincial, territorial, and federal levels appear to be similar: all but one province stated that they did not have the capacity to respond to climate change. This was rather alarming considering that the provinces and territories are responsible for over $95 \%$ of Canada's protected areas (in terms of total number of sites).

There is an evident lack of strategic response in the policy, system planning, and management program areas of various jurisdictions. No strategy (or action plan) specific to any protected areas agency has been developed to help with guiding decision-making at the regional or park levels. This lack of response in most of the policy, planning, and management functions gives the impression that many jurisdictions may be unprepared to deal effectively with the more widespread and complex impacts that are anticipated as the climate continues to change throughout the 21 st century. Moreover, only about one-half of the agencies participating in the survey are actively involved in climate change dialogue and capacitybuilding initiatives (e.g., staff participation in workshops and conferences and staff training, etc.), which suggests that adaptive capacity will remain low for the foreseeable future. The large turnover and loss of staff that has been common to protected areas agencies over the past decade (e.g., ECO 2007; CPAWS 2008) further challenges the maintenance of adequate internal expertise and experience with climate change adaptation.

Given the multi-scale and cross-jurisdictional nature of climate change impacts, independent top-down approaches will not suffice in the long-term. A more integrated and collaborative approach within Canada and on a continental scale will be needed if protected areas agencies are to address the climate change issue effectively. Nearly all protected areas agencies participating in the survey $(86 \%)$ noted that they would be willing to participate in

Figure 5. Selected preferences from among suggested approaches to climate change adaptation (percent of protected areas agencies respondents; respondents could select more than one option).

Sharing in a Canada-wide Protected Areas Collaborative Effort on Climate Change

Operating within a Comprehensive, Agency-based Strategy

Coping with Issues on an "As Needed" Basis

No Specific Adaptation Strategy
$83 \%$

$40 \%$

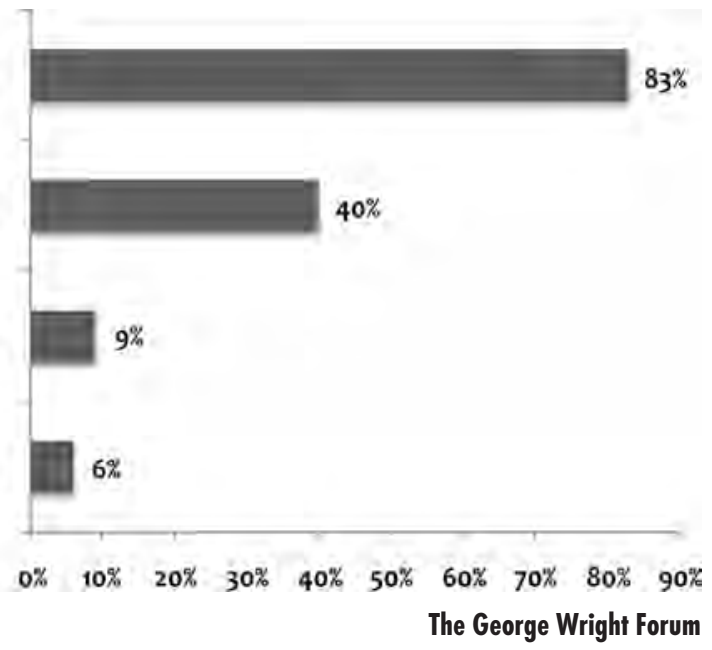




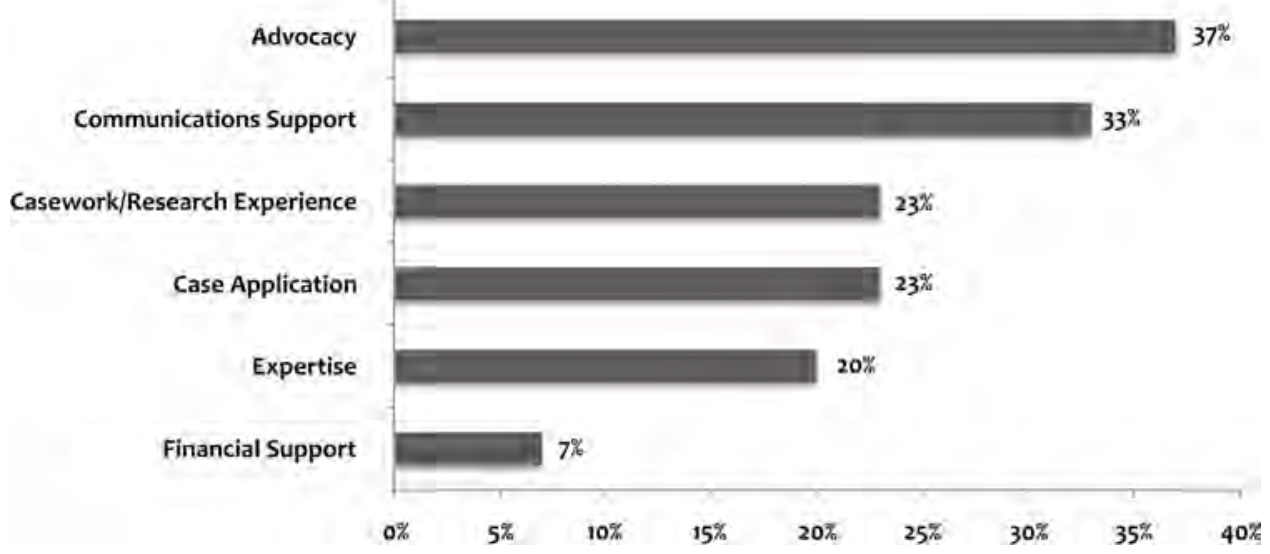

Figure 6. Resources that protected areas agencies would be willing to provide for a climate change and protected areas working group or a nationwide conference on the topic (respondents could select more than one option).

either a nationwide working group or conference on climate change and protected areas. Furthermore, $83 \%$ held the position that a nationwide collaborative effort on climate change would be a suitable approach to adaptation (Figure 5).

For climate change adaptation to be effective, it must go hand-in-hand with good communication about climate change, its impacts, and associated agency management responses (Schweizer et al. 2009). Fortunately, there appears to be some capacity to communicate climate change messages to staff, members of specific associations and groups, and to the general public. One-third of respondents $(33 \%)$ indicated that they would be prepared to provide advocacy and communications support to a national working group or national workshop (Figure 6). On the other hand, few agencies are in a position to provide financial resources $(7 \%)$ or human assets (i.e., scientific expertise) $(20 \%)$.

\section{Conclusions}

Climate change is not a remote future event for biodiversity and protected areas planning and management. The varied impacts of a changing climate are becoming more and more evident at locations around the world, including Canada (IPCC 2007a; Lemmen et al. 2008). Parry et al. (2009) and others previously (e.g., Stehr and von Storch 2005) have stressed that the risks and dangers of failing mitigation efforts (i.e., reductions in GHG emissions) without adaptive strategies would have serious implications for society and that to ignore adaptation would be similarly perilous for nature. Several recent studies have indicated that with current government commitments to GHG emission reductions, temperatures would exceed $2^{\circ} \mathrm{C}$ of average global warming by 2100 (Hansen et al. 2007; Anderson and Bows 2008; Meinshausen et al. 2009; Parry et al. 2009; Rogelj et al. 2009). This level of warming would exceed the thresholds identified by the IPCC wherein 20-30\% of Earth's plant and animal species will likely be at increased risk of extinction (IPCC 2007b, 48).

Although there is much uncertainty about the timing, extent, and manner in which 
ecosystems and other protected areas assets (e.g., recreational opportunities) might respond to evolving climatic conditions, it is critically important that natural asset management agencies begin to identify, assess, and implement adaptation options that could reduce the vulnerability of Canada's protected areas (and their constituent biodiversity) to climate change. The Report of the Commissioner of the Environment and Sustainable Development emphasized that failing to invest adequately in the area of climate change adaptation will "undermine Canada's ability to make wise decisions" (Gelinas 2006, 20). The report also called on all governments to begin developing action plans that cut across departments, to work with other levels of government to develop clear priorities, and to find new ways to connect researchers with decision-makers (Gelinas 2006).

Canada, a world leader in the protected areas movement, has made some progress in recognizing and documenting the threats and opportunities associated with climate change, with work initiated in some agencies that begins dealing with the issue (e.g., Scott and Suffling 2000; Scott et al. 2002; Lemieux and Scott 2005; Scott and Lemieux 2005, 2007; Welch 2005; Jones and Scott 2006a, 2006b; Lemieux et al. 2010, 2011; Lemieux and Scott, in press). With limited resources at their disposal, it is encouraging that many protected areas agencies have progressed as much as they have on climate change adaptation. However, adaptation within Canada's protected areas jurisdictions is occurring independently, without national coordination, and there continues to be a relatively slow response by practitioners both in terms of the development and implementation of relevant policy and management strategies.

Why has there been so little practical climate change adaptation within the protected areas sector? First, the extant scientific literature on the subject has been dominated by ecology and has failed to integrate social science considerations, including decision-making and other management objectives of protected areas (Lemieux and Scott 2005; Welch 2005; Heller and Zavaleta 2009; Lemieux et al. 2010). Second, the high degree of uncertainty in assessments of climate change impacts can make it difficult for a manager to translate results from climate change assessments into practical management decisions (Dessai et al. 2009; Lawler et al. 2009; Lemieux et al. 2011). Third, the protected areas and climate change adaptation literature has been described as too generic with relatively little direct investigation into the desirability and feasibility of adaptation options by those actually responsible for the planning and management of protected areas (Scott and Lemieux 2005). As Welch (2005) emphasized, the limited climate change literature on protected areas provides little guidance to protected area managers. Finally, the results of our survey reveal an overriding need for more resources to build capacity for effective management within protected areas institutions. Such findings are consistent with other natural resource sectors in Canada (e.g., forestry) that have also experienced challenges in their efforts to mainstream climate change into policy, planning, and management frameworks (e.g., Ogden and Innes 2009).

While constraints such as limited financial resources, limited capacity, and lack of understanding of real or anticipated climate change impacts need to be eliminated, an immediate concern for protected areas agencies is the further strengthening and development of relational networks at all scales. The survey results show that climate change education, capacity-building, and information dissemination has largely occurred through external con- 
ferences (i.e., piggy-backing) rather than through formally established networks. Recognizing complementary strengths and weaknesses between and among agencies will be critical in any collaborative effort to address climate change.

Collaboration could be enhanced through the establishment of professional networks both within Canada and on a continental scale between Canada, the United States, and Mexico. Protected areas will remain the fundamental building blocks of national and international conservation strategies and their role in safeguarding biodiversity will become even more critical in an era characterized by rapid climate change. It is to be hoped that extreme events, such as species extinctions, are not required to raise public and practitioner awareness of climate change in order to motivate proactive conservation action. Ultimately, the results presented here reveal that inadequate investment in climate change adaptation may lead protected area managers to maintain the status quo or rely on reactive adaptation (vs. proactive adaptation) despite concerns about the long-term viability of current planning and management practices. Considering the short-term projections of species turnover and loss resulting from climate change, the potential for non-linear ecological responses (in other words, ecological surprises), the length of time required for species and ecosystem response to management interventions, and the relatively slow process of implementing new policies within protected areas agencies, the time to begin developing proactive, and integrative climate change adaptation strategies is now.

\section{Acknowledgments}

This report is a product of the cooperative effort of many individuals within the Canadian protected areas community. The authors would like to express sincere gratitude to all those who participated in the Canadian Council on Ecological Areas (CCEA) protected areas and climate change survey-without your participation and input this research would have not been possible. Please know that your tremendous contributions are greatly appreciated by the authors. The CCEA board, directors, and jurisdictional representatives of CCEA provided valuable support throughout the project. Review comments provided by Jill S. Baron (US Geological Survey, Colorado State University), and two anonymous reviewers helped improve the article. This article would have not been possible without funding provided by CCEA, the Social Sciences and Humanities Research Council of Canada, and Fulbright Canada. Finally, we thank Stephen D. Murphy (Centre for Applied Sciences in Ontario Protected Areas, University of Waterloo), Christopher J. Kirkey and staff (Center for the Study of Canada, State University of New York-Plattsburgh), Jill S. Baron, and David Harmon (World Commission on Protected Areas-North America and George Wright Society) for providing valuable in-kind support.

[Ed. note: This article originally appeared in The Canadian Geographer / Le Géographe canadien 33, no. 3; doi: 10.1111/j.1541-0064.2010.00336.x, 2011. (C) 2011 Canadian Association of Geographers. Reprinted by permission.] 


\section{References}

Anderson, K., and A. Bows. 2008. Reframing the climate change challenge in light of post2000 emission trends. Philosophical Transactions of the Royal Society A 366 (1882): 3863-3882; doi: 10.1098/rsta.2008.0138.

Barnosky, A.D., E.A. Hadly, and C.J. Bell. 2003. Mammalian response to global warming on varied temporal scales. Fournal of Mammalogy 84 (2): 354-368.

Baron, J.S., L. Gunderson, C.D. Allen, E. Fleishman, D. Mckenzie, L.A. Meyerson, J. Oropeza, and N. Stephenson. 2009. Options for national parks and reserves for adapting to climate change. Environmental Management 44 (6): 1033-1042; doi: 10.1007/s00267009-9296-6.

British Columbia Ministry of Water, Land and Air Protection. 2002. Indicators of Climate Change for British Columbia. Victoria, BC: British Columbia Ministry of Water, Land and Air Protection. Online at http://www.env.gov.bc.ca/cas/pdfs/indcc.pdf.

Burton, I., S. Huq, B. Lim, O. Pilifosova, and E.L. Schipper. 2002. From impacts assessment to adaptation priorities: the shaping of adaptation policies. Climate Policy 2: 145-159; doi: $10.3763 / \mathrm{cpol} .2002 .0217$.

CBD [Convention on Biological Diversity]. 1992. Convention on Biological Diversity. Nairobi: United Nations Environment Programme. Online at http://www.cbd.int/doc/ legal/cbd-un-en.pdf.

. 2009. Connecting Biodiversity and Climate Change Mitigation and Adaptation: Report of the Second Ad Hoc Technical Expert Group on Biodiversity and Climate Change. CBD Technical Series no. 41. Montreal, QC: Secretariat of the CBD. Online at http:// www.cbd.int/doc/publications/cbd-ts-41-en.pdf.

CCEA [Canadian Council on Ecological Areas]. 2009. Strategic Plan 2010-2020. Gatineau, QC: CCEA Secretariat, Environment Canada.

- 2010. Conservation Areas Reporting and Tracking System (CARTS). Online at http:// ccea.org/en carts.html.

- n.d. Mission statement. Online at http://www.ccea.org/ en mission.html.

CCME [Canadian Council of Ministers of the Environment]. 2003. Climate, Nature, People: Indicators of Canada's Changing Climate. Winnipeg, MB: CCME. Online at http:// www.ccme.ca/assets/pdf/cc_ind_full_doc_e.pdf .

CPAWS [Canadian Parks and Wilderness Society]. 2008. The State of Alberta's Parks and Protected Areas Report. Edmonton, AB: CPAWS. Online at http://www.cpawsnab.org/ factsheets/report_summary_for_online_distribution.pdf

Dessai, S., M. Hulme, and R. Lempert. 2009. Do we need better predictions to adapt to a changing climate? Eos 90 (13): 111-112.

ECO [Environmental Commissioner of Ontario]. 2007. Doing Less with Less: How Shortfalls in Budget, Staffing and Inhouse Expertise are Hampering the Effectiveness of MOE and MNR. Special report to the Legislative Assembly of Ontario. Toronto: ECO.

Environment Canada. 2006. Canadian Protected Areas Status Report, 2000-2005. Gatineau, QC: Environment Canada. Online at http://www.ec.gc.ca/Publications/default.asp?lang=En\&xml=5A5F8028-B497-4441-92DE-4015F1E4F5D1.

Gelinas, J. 2006. Report of the Commissioner of the Environment and Sustainable Develop- 
ment to the House of Commons. Ottawa, ON: Office of the Auditor General of Canada. Government of Canada. 2000. Canada National Parks Act 2000, c. 32. Ottawa, ON: Government of Canada. Online at http://www.pc.gc.ca/docs/bib-lib/ /media/docs/biblib/pdfs/acts/cnpa_e.ashx.

——_. 2003. Canadian Species at Risk Act. Chapter 29. Ottawa, ON: Government of Canada.

-_- 2009. Canada's Fourth National Report to the Convention on Biological Diversity. Ottawa, ON: Government of Canada.

Government of Ontario. 2007. Ontario Provincial Parks and Conservation Reserves Act 2006, Chapter 12. Online at http://www.elaws.gov.on.ca/html/statutes/english/elawsstatutes $06 \mathrm{p} 12 \mathrm{e} . \mathrm{htm}$.

Hamann, A., and T. Wang. 2005. Potential Effects of Climate Change on Ecosystem and Tree Species Distribution in British Columbia. Vancouver, BC: Centre for Forest Gene Conservation, Department of Forest Sciences, University of British Columbia.

Hannah, L., G. Midgley, and D. Millar. 2002. Climate change-integrated conservation strategies. Global Ecology and Biogeography 11: 485-495.

Hansen, J., et al. 2007. Dangerous human-made interference with climate: A GISS model study. Atmospheric Chemistry and Physics 7: 2287- 2312; doi: 10.5194/acp-7-22872007.

Heller, N., and E. Zavaleta. 2009. Biodiversity management in the face of climate change: A review of 22 years of recommendations. Biological Conservation 142: 14-32; doi: 10. 1016/j.biocon.2008.10.006.

Henderson, N., E. Hogg, E. Barrow, and B. Dolter. 2002. Climate Change Impacts on the Island Forests of the Great Plains and the Implications for Nature Conservation Policy: The Outlook for Sweet Grass Hills (Montana), Cypress Hills (Alberta-Saskatchewan), Moose Mountain (Saskatchewan), Spruce Woods (Manitoba-North Dakota). Regina, SK: Prairie Adaptation Research Collaborative.

Herrod, J.S., and J.M. West, eds. 2008. Preliminary Review of Adaptation Options for Climate-sensitive Ecosystems and Resources: Final Report. Washington, DC: US Climate Change Science Program.

IPCC [Intergovernmental Panel on Climate Change]. 2007a. Climate Change 2007: Climate Change Impacts, Adaptation, and Vulnerability-Summary for Policymakers. Working Group II Contribution to the IPCG Fourth Assessment Report. Cambridge, UK: Cambridge University Press.

—__ 2007b. Climate Change 2007: The Physical Science Basis. Working Group I Contribution to the IPCC Fourth Assessment Report. Cambridge, UK: Cambridge University Press.

Jones, B., and D.J. Scott. 2006a. Climate change, seasonality and visitation to Canada's national parks. Fournal of Parks and Recreation Administration 24 (2): 42-62.

2006b. Implications of climate change for visitation to Ontario's provincial parks. Leisure 30 (1): 233-261.

Keenleyside, K. 2010. Personal communication with senior science and policy advisor, Parks Canada, Ecological Integrity Branch. March. 
Lawler, J.J., S.L. Shafer, D. White, P. Kareiva, E.P. Maurer, A.R. Blaustein, and P.J. Bartlein. 2009. Projected climate-induced faunal change in the Western Hemisphere. Ecology 90 (3): 588-597; doi: 10.1890/08-0823.1.

Lemieux, C.J., T.J. Beechey, D.J. Scott, and P.A. Gray. 2010. Protected Areas and Climate Change in Canada: Challenges and Opportunities for Adaptation. CCEA Occasional Paper no. 19. Ottawa, ON: CCEA Secretariat.

Lemieux, C.J., and D.J. Scott. 2005. Climate change, biodiversity conservation and protected area planning in Canada. The Canadian Geographer 49 (4): 384-399; doi: 10.1111/ j.0008-3658.2005.00103.x.

Lemieux, G.J., D.J. Scott, P.A. Gray, and R.G. Davis. 2007. Climate Change and Ontario's Provincial Parks: Towards an Adaptation Strategy. Climate Change Research Report no. CCRR-06. Sault Ste. Marie, ON: Ontario Ministry of Natural Resources.

Lemieux, C.J., D.J. Scott, R.G. Davis, and P.A. Gray. 2008. Changing Climate, Challenging Choices: Ontario Parks and Climate Change Adaptation. Ottawa, ON: Natural Resources Canada, Climate Change Impacts and Adaptation Program. Online at http:// www.environment.uwaterloo.ca/geography/faculty/danielscott/PDFFiles/NRCANReport-FINAL.pdf.

Lemieux, C.J. and D.J. Scott. In press. Changing climate, challenging choices: identifying and evaluating climate change adaptation options for protected area management in Ontario, Canada. Environmental Management; doi: 10.1007/s00267-011-9700-x.

Lemmen, D.S., F.J. Warren, J. Lacroix, and E. Bush, eds. 2008. From Impacts to Adaptation: Canada in a Changing Climate 2007. Ottawa, ON: Government of Canada.

Malcolm, J.R., L. Canran, R.P. Neilson, L. Hansen, and L. Hannah. 2006. Global warming and extinctions of endemic species from biodiversity hotspots. Conservation Biology 20 (2): 538-548; doi: 10.1111/j.1523-1739.2006.00364.x.

Malcolm, J.R., C. Liu, L.B. Miller, T. Allnutt, and L. Hansen. 2002. Habitats at Risk: Global Warming and Species Loss in Globally Significant Terrestrial Ecosystems. Gland, Switzerland: Worldwide Wildlife Fund.

Malcolm, J.R., A. Markham, R.P. Neilson, and M. Garaci. 2002. Estimated migration rates under scenarios of global climate change. Fournal of Biogeography 29: 835-849; doi: 10.1046/j.1365-2699.2002.00702.x.

Mckenney, D.W., J.H. Pedlar, K. Lawrence, K. Campbell, and M.F. Hutchinson. 2007a. Potential impacts of climate change on the distribution of North American trees. BioScience 57 (11): 939-948; doi: 10.1641/B571106.

-__ 2007b. Beyond traditional hardiness zones: Using climate envelopes to map plant range limits. BioScience 57 (11): 929-937; doi: 10.1641/B571105.

Meinshausen, M., N. Meinshausen, W. Hare, S.C.B. Raper, K. Frieler, R. Knutti, D.J. Frame, and M.R. Allen. 2009. Greenhouse-gas emission targets for limiting global warming to $2^{\circ} \mathrm{C}$. Nature 458 (7242): 1158-1162; doi: 10.1038/nature08017.

Millennium Ecosystem Assessment. 2005. Ecosystems and Human Well-being: Biodiversity Synthesis. Washington, DC: World Resources Institute.

Ogden, A.E., and J.L. Innes. 2009. Application of structured decision making to an assessment of climate change vulnerabilities and adaptation options for sustainable forest 
management. Ecology and Society 14 (1): 11.

Opdam, P., and D. Wascher. 2004. Climate change meets habitat fragmentation: linking landscape and biogeographical scale levels in research and conservation. Biological Conservation 117: 285-297; doi: 10.1016/j.biocon.2003.12.008.

Parks, J.J. 2006. Climate Change Adaptations for Land Use Planners. Report submitted to Natural Resources Canada, Climate Change Impacts and Adaptation Program. Online at http://adaptation.nrcan.gc.ca/projdb/pdf/178b_e.pdf.

Parks Canada Agency. 2010. The Climate is Changing in Our National Parks. Ottawa, ON: Parks Canada Agency. Online at http://www.pc.gc.ca/docs/v-g/ie-ei/cc/index.aspx.

Parmesan, C. 2006. Ecological and evolutionary responses to recent climate change. Annual Review of Ecology, Evolution, and Systematics 37: 637-669.

Parry, M., J. Lowe, and C. Hanson. 2009. Overshoot, adapt, and recover. Nature 458: 11021103; doi: 10.1038/4581102a.

Pearson, D., and I. Burton. 2009. Adapting to Climate Change in Ontario: Towards the Design and Implementation of a Strategy and Action Plan. The Expert Panel on Climate Change Adaptation Report to the Minister of the Environment. Toronto: Queen's Printer for Ontario.

Pielke, R.A. 1998. Rethinking the role of adaptation in climate policy. Global Environmental Change 8 (2): 159-170; doi: 10.1016/S0959-3780(98)00011-9.

Pounds, J.A., and R. Puschendorf. 2004. Clouded futures. Nature 427: 107-109.

Rogelj, J., B. Hare, J. Nabel, K. Macey, M. Schaeffer, K. Markmann, and M. Meinshausen. 2009. Halfway to Copenhagen, no way to $2^{\circ} \mathrm{C}$. Nature Reports Climate Change (June): 81- 83; doi: 10.1038/climate.2009.57.

Root, T.L., J.T. Price, K.R. Hall, S.H. Schneider, C. Rosenzweig, and J.A. Pounds. 2003. Fingerprints of global warming on wild animals and plants. Nature 421: 57-60; doi: 10.1038/nature01333.

Schweizer, S., J.L. Thompson, T. Teel, and B. Bruyere. 2009. Strategies for communicating about climate change impacts on public lands. Science Communication 31 (2): 266274; doi: 10.1177/1075547009352971.

Scott, D.J., and C.J. Lemieux. 2005. Climate change and protected area policy and planning in Canada. The Forestry Chronicle 81 (5): 696-702. Online at http://nofc.cfs.nrcan.gc. ca/bookstore pdfs/25752.pdf.

Scott, D.J., and C.J. Lemieux. 2007. Climate change and protected areas policy, planning and management in Canada's boreal forest. The Forestry Chronicle 83 (3): 347-357.

Scott, D.J., C.J. Lemieux, and L. Malone. 2011. Climate services to support sustainable tourism and adaptation to climate change. Climate Research; doi: 10.3354/cr00952.

Scott, D.J., J.R. Malcolm, and C.J. Lemieux. 2002. Climate change and modeled biome representation in Canada's national park system: Implications for system planning and park mandates. Global Ecology and Biogeography 11: 475-484.

Scott, D.J., and R. Suffling. 2000. Climate Change and Canada's National Parks. Toronto: Environment Canada.

Smit, B., I. Burton, R.J.T. Klein, and R. Street. 1999. The science of adaptation: A framework for assessment. Mitigation and Adaptation Strategies for Global Change 4: 199- 
213; doi: 10.1023/A:1009652531101.

Stehr, N., and H. Von Storch. 2005. Introduction to papers on mitigation and adaptation strategies for climate change: Protecting nature from society or protecting society from nature?. Environmental Science and Policy 8: 537-540; doi: 10.1016/j.envsci.2005.08. 001.

Stern, N. 2006. The Economics of Climate Change: The Stern Review. Cambridge, UK: Cambridge University Press.

Thomas, C. D., et al. 2004. Extinction risk from climate change. Nature 427: 145-148; doi: 10.1038/nature02121.

Thomas, C.D., A.M.A. Franco, and J.K. Hill. 2006. Range retractions and extinction in the face of climate warming. Trends in Ecology and Evolution 21 (8): 415-416; doi: 10. 1016/j.tree.2006.05.012.

Thompson, A., P. Robbins, B. Sohngen, J. Arvai, and T. Koontz. 2006. Economy, politics, and institutions: from adaptation to adaptive management in climate change. Climatic Change 78: 1-5; doi: 10.1007/s10584-006-9095-5.

Vandall, J., N. Henderson, and J. Thorpe. 2006. Suitability and Adaptability of Current Protected Area Policies under Different Climate Change Scenarios: The Case of the Prairie Ecozone, Saskatchewan. Saskatoon, SK: Saskatchewan Research Council.

Vedwan, N., and R.E. Rhoades. 2001. Climate change in the Western Himalayas of India: A study of local perception and response. Climate Research 19: 109-117.

Welch, D. 2005. What should protected areas managers do in the face of climate change? The George Wright Forum 22 (1): 75-93.

West, J.M., S.H. Julius, P. Kareiva, C. Enquist, J.J. Lawler, B. Peterson, A.E. Johnson, and M.R. Shaw. 2009. US natural resources and climate change: Concepts and approaches for management adaptation. Environmental Management 44 (6): 1001-1021; doi: 10. 1007/s00267-009-9345-1.

Wiersma, Y.F., T.J. Beechey, B.M. Oosenbrug, and J.C. Meikle. 2006. Protected Areas in Northern Canada: Designing for Ecological Integrity. CCEA Occasional Paper no. 16. Ottawa, ON: CCEA.

WWF [World Wildlife Fund]. 2003. Buying Time: A User's Manual for Building Resistance and Resilience to Climate Change in Natural Systems. Washington, DC: WWF International.

Christopher J. Lemieux, Centre for Applied Sciences in Ontario Protected Areas / Interdisciplinary Centre on Climate Change, Department of Geography and Environmental Management, University of Waterloo, Waterloo, Ontario N2L 3G1 Canada; cjlemieux@ uwaterloo.ca

Thomas J. Beechey, Canadian Council on Ecological Areas (CCEA), 91 Cooper Street, Cambridge, Ontario N3C 2N5 Canada; tombeechey@sympatico.ca

Daniel J. Scott, Department of Geography and Environmental Management, University of Waterloo, Waterloo, Ontario N2L 3G1 Canada; dj2scott@envmail.uwaterloo.ca

Paul A. Gray, Applied Research and Development Branch, Ministry of Natural Resources, 300 Water Street, Peterborough, Ontario K9J 8M5 Canada; paul.gray@ontario.ca 